\title{
HUBUNGAN ANTARA PENGETAHUAN TENTANG PROSES MENUA DENGAN TINGKAT DEPRESI PADA LANSIA DI DESA MAJASTO SUKOHARJO
}

\author{
Dinar Ariasti ${ }^{1}$, Joko Sutrisno ${ }^{2}$
}

\begin{abstract}
The role of knowledge in dealing with depression is to help individuals recognize the existence in this world by expanding self-awareness, find himself again and is responsible for the direction of his life. Initial survey results indicate that the 3 (three) responden experienced the characteristics of someone who is depressed by the low level of knowledge. The purpose of this study was to determine the relationship of knowledge about the aging process with a level of depression in elderly Majasto Village, District Tawangsari, Sukoharjo.

Subject of this study was elderly people in the village Majasto, based on an initial survey found as many as 65 elderly. This research method in this study an analytic correlation with cross sectional approach. Data collection tool used is a questionnaire to measure the level of knowledge of the aging process with depression from Majasto village.

Results of the study there were respondents with a high level of knowledge nothing is severely depressed, two respondents had moderate depression and 10 respondents did not experience depression and 3 respondents with a low level of knowledge into a deep depression and 2 nd respondents had moderate depression. the results of Chi-Square test with SPSS version 18.0 with $\alpha=5 \%(0: 05)$ was obtained $p<0.001$ to $p$ value of $<0.05$, which means that Ho refused and $\mathrm{Ha}$ accepted. Conclusion of this study there is a relationship between the level of knowledge about the aging process with a level of depression in residents in the village Majasto Tawangsari Sukoharjo.
\end{abstract}

Keywords: knowledge, depression

\section{PENDAHULUAN}

Menua atau menjadi tua adalah suatu keadaan yang terjadi di dalam kehidupan manusia. Proses menua merupakan proses sepanjang hidup, tidak hanya dimulai dari suatu waktu tertentu, tetapi dimulai sejak permulaan kehidupan. Menjadi tua merupakan proses alamiah, yang berarti seseorang melalui tiga tahap kehidupannya, yaitu anak, dewasa, dan tua. Proses menua merupakan proses sepanjang hidup, tidak hanya dimulai dari suatu waktu tertentu, tetapi dimulai sejak permulaan kehidupan. (Nugroho, 2008)

Masa dewasa tua (lansia) dimulai setelah pensiun, biasanya antara 65 dan 75 tahun. (Potter and Perry, 2005) Menurut perkiraan biro pusat statistik, pada tahun 2005 di
Indonesia, terdapat 18.283.107 penduduk lanjut usia. Jumlah ini akan melonjak mencapai 33 juta orang lanjut usia (12\% dari total penduduk).

Memasuki usia tua berarti mengalami kemunduran, misalnya kemunduran fisik yang ditandai dengan kulit yang mengendur, rambut memutih, gigi mulai ompong, pendengaran kurang jelas, penglihatan semakin memburuk, gerakan lambat, dan figur tubuh yang tidak proporsional. Dari beberapa lansia yang mengalami kemunduran fisik maupun kemunduran psikis kadang menyebabkan lansia mengalami depresi. (Nugroho, 2008)

Depresi bukan merupakan kelemahan atau kemalasan tetapi 
ketidakberdayaan seseorang untuk mengatasi masalahnya. Depresi bukan merupakan hal yang normal pada lansia walaupun depresi biasa terjadi pada lansia. Kira-kira 3 dari 100 orang lansia berusia di atas 65 tahun mengalami depresi. Angka ini akan meningkat pada lansia pada usia 80 tahun atau lebih. (Keliat, et al., 2011)

Depresi pada lansia merupakan permasalahan kesehatan jiwa (mental health) yang serius dan kompleks, tidak dikarenakan aging process tetapi juga faktor lain yang saling terkait. Sehingga dalam mencari penyebab depresi pada lansia harus dengan multiple approach. (Aspiani, 2014) Data pravalensi depresi pada usia lanjut di Indonesia diperoleh dari ruang rawat akut geriatri dengan kejadian depresi sebanyak 76,3\%. Dengan proporsi pasien gariatri dengan depresi ringan sebanyak $44,1 \%$, depresi sedang $18 \%$, depresi berat $3,2 \%$. (Sudoyo, 2007)

Akibat depresi tersebut lansia mengalami beberapa perilaku yang buruk seperti merasa putus asa, kebersihan diri terabaikan, nafsu makan menurun tidak berguna dan bahkan timbul ide-ide bunuh diri. Bagi keluarga dampak dari depresi pada lansia yang ada di keluarganya adalah keluarga sering kuwalahan akibat perbuatan yang dilakukan oleh para lansia. Dampak bagi masyarakat hubungan sosial terhadap lansia menurun. Untuk mencegah terjadinya dampak tersebut dilakukan beberapa pendekatan yaitu pendekatan psikodinamik, pendekatan perilaku belajar, pendekatan kognitif, pendekatan humanistik eksistensial, pendekatan fisiologis. Sedangkan peran pengetahuan dalam mengatasi depresi adalah membantu individu menyadari keberadaannya di dunia ini dengan memperluas kesadaran diri, menemukan dirinya kembali dan bertanggung jawab terhadap arah hidupnya. (Aspiani, 2014)

Kelurahan Majasto merupakan salah satu kelurahan di Kecamatan Tawangsari Kabupaten Sukoharjo. Hasil survey awal diperoleh data jumlah lansia ada 65 orang. Hasil dari wawancara menunjukkan bahwa 3 (tiga) lansia mengalami ciri-ciri seseorang yang depresi seperti kehilangan minat dan kegembiraan, harga diri rendah, menurunnya aktivitas konsentrasi dan perhatian berkurang yang disebabkan oleh penurunan kondisi fisik akibat penuaan. Dari beberapa lansia yang menunjukkan tandatanda depresi mengatakan sudah tahu tentang proses menua, namun ada juga yang belum paham bagaimana proses menua yang terjadi sehingga dapat menyebabkan depresi. Namun demikian, sampai saat ini belum ada penelitian secara ilmiah terkait dengan masalah tersebut.

Melihat latar belakang di atas maka penulis tertarik mengadakan penelitian mengenai "Hubungan pengetahuan tentang proses menua dengan tingkat depresi pada lansia di Kelurahan Majasto Kecamatan Tawangsari Kabupaten Sukoharjo".

\section{TUJUAN PENELITIAN}

Tujuan umum untuk mengetahui hubungan pengetahuan tentang proses menua dengan tingkat depresi pada lansia di Desa Majasto, Kecamatan Tawangsari, Sukoharjo.

Tujuan khusus untuk mengetahui gambar tingkat pengetahuan tentang proses menua dan gambaran tentang tingkat depresi pada lansia di desa Majasto Tawangsari Sukoharjo.

\section{DESAIN PENELITIAN}

Penelitian ini merupakan penelitian analitik korelasi dengan pendekatan cross sectional. Tingkat pengetahuan sebagai variabel 
bebas (independent variable) dan tingkat depresi sebagai variabel terikat (dependent variable). Alat pengumpulan data yang digunakan adalah kuesioner untuk mengukur pengetahuan proses menua dengan tingkat depresi dengan mencari data primer dari desa Majasto. Uji statistik dengan Chi-Square program SPSS versi 18.0 dengan $\alpha$ $=5 \%(0.05)$

\section{POPULASI, SAMPEL DAN TEKNIK SAMPLING}

Populasi merupakan seluruh subyek atau objek dengan karakteristik tertentu yang akan diteliti. Bukan hanya objek atau subjek yang dipelajari saja tetapi seluruh karakteristik atau sifat yang dimiliki subjek atau objek tersebut. (Hidayat, 2009) Populasi pada penelitian ini adalah seluruh lansia yang ada di desa Majasto Tawangsari Sukoharjo, berdasarkan survey awal didapatkan sebanyak 65 lansia.

Sampel merupakan bagian populasi yang akan diteliti atau sebagian jumlah dari karakteristik yang dimiliki oleh populasi. (Hidayat, 2009) Pada penelitian ini peneliti mengambil sampel lansia di desa Majasto Tawangsari Sukoharjo, dengan besar sampel 65 orang di mana populasi dipakai sebagai sampel dalam penelitian.

Teknik sampling merupakan suatu proses seleksi sampel yang digunakan dalam penelitian dari populasi yang ada, sehingga jumlah sampel akan mewakili keseluruhan populasi yang ada. (Hidayat, 2009) Pengambilan sampel pada penelitian ini menggunakan sampling jenuh yaitu dengan mengambil semua anggota populasi menjadi sampel, dimana didapatkan sampel seluruh lansia yang berada di desa Majasto.

Pada penelitian yang berjudul hubungan antara pengetahuan tentang proses menua dengan tingkat depresi pada lansia di desa
Majasto Tawangsari Sukoharjo peneliti menggunakan alat penelitian atau instrumen penelitian dengan lembar kuesioner yang berisi 30 pertanyaan untuk tingkat pengetahuan tentang proses menua dan 30 pertanyaan untuk tingkat depresi dengan menggunakan GDS (Geriatric Depression Scale ).

Pengumpulan data merupakan kegiatan peneliti untuk mengumpulkan data. Sebelum melakukan pengumpulan data, perlu dilihat alat ukur pengumpulan data agar dapat memperkuat hasil penelitian. Alat ukur pengumpulan data tersebut antara lain dapat berupa kuesioner, observasi, wawancara, atau gabungan alat ukur penelitian ketiganya. (Hidayat, 2008)

Dalam penelitian ini, alat pengumpulan data yang digunakan adalah kuesioner untuk mengukur pengetahuan proses menua dengan tingkat depresi dengan mencari data primer dari desa Majasto Tawangsari Sukoharjo. Pengolahan data dilakukan dengan dengan $\mathrm{Chi}$ Square program SPSS versi 18.0 dengan $\alpha=5 \%(0.05)$

\section{HASIL PENELITIAN}

Penelitian dilakukan di Desa Majasto Kecamatan Tawangsari Kabupaten Sukoharjo mulai bulan Juni 2016 sampai dengan bulan Juli 2016 dengan jumlah responden 65 lanjut usia yang tinggal di desa tersebut.

Di bawah ini akan dipaparkan hasil penelitian tentang hubungan pengetahuan tentang proses menua dengan tingkat depresi pada lansia di Desa Majasto Tawangsari Sukoharjo. 
Tabel 1.

Distribusi Frekuensi Tingkat

Pengetahuan Tentang Proses Menua di Desa Majasto

\begin{tabular}{ccc}
\hline Tingkat Pengetahuan & $\mathrm{f}$ & $\%$ \\
Tentang Proses Menua & & $\%$ \\
\hline Tinggi & 12 & 18 \\
Sedang & 48 & 74 \\
Rendah & 5 & 8 \\
\hline Jumlah & 65 & 100 \\
\hline
\end{tabular}

Dari tabel di atas ditemukan ada 12 responden (18\%) mempunyai pengetahuan tinggi tentang proses menua dan sebagian besar responden atau 48 orang (74\%) mempunyai pengetahuan sedang atau cukup. Dapat dicermati bahwa warga lanjut usia di Desa Majasto Sukoharjo sebagian besar berpengetahuan cukup atau sedang tentang proses menua. Hal ini dikarenakan warga lanjut usia banyak memperoleh informasi tentang proses menua dari mediamedia yang dimiliki responden seperti televisi, majalah atau koran. $\mathrm{Di}$ desa Majasto juga terdapat posyandu lansia yang rutin melaksanakan kegiatan posyandu dan penyuluhan-penyuluhan tentang proses menua mencakup perubahan-perubahan yang terjadi baik dari segi fisik maupun psikis. Hal tersebut sangat membantu lansia dalam menghadapai masa tua yang dialaminya. Tabel 2.

Distribusi Frekuensi Tingkat Depresi di Desa Majasto

\begin{tabular}{|c|c|c|}
\hline Tingkat Depresi & $f$ & $\%$ \\
\hline Depresi berat & 6 & 9 \\
\hline Depresi sedang & 23 & 36 \\
\hline Tidak depresi & 36 & 55 \\
\hline Jumlah & 65 & 100 \\
\hline $\begin{array}{l}\text { Dari tabel di a } \\
\text { responden }(9 \%) \\
\text { berat, } 23 \text { re } \\
\text { mengalami depr } \\
\text { sebagian besar re } \\
36 \text { orang }(55 \%) \\
\text { depresi. }\end{array}$ & $\begin{array}{r}\text { ond } \\
\mathrm{s}\end{array}$ & $\begin{array}{l}\text { kan } 6 \\
\text { depresi } \\
(36 \%) \\
\text { g dan } \\
\text { jumlah } \\
\text { igalami }\end{array}$ \\
\hline
\end{tabular}

Tabel 3.

Hasil Uji Statistik Tingkat

Pengetahuan Tentang Proses

Menua Dengan Tingkat Depresi di

Desa Majasto Tawangsari Sukoharjo

\begin{tabular}{lccc}
\hline & Value & df & $\begin{array}{c}\text { Asymp.Sig. } \\
\text { (2-sided) }\end{array}$ \\
\hline $\begin{array}{l}\text { Pearson } \\
\text { Chi-Square }\end{array}$ & $21,463^{\mathrm{a}}$ & 4 &, 000 \\
$\begin{array}{l}\text { Likelihood } \\
\text { Ratio } \\
\text { Linear- }\end{array}$ & 17,646 & 4 &, 001 \\
by-Linear \\
$\begin{array}{l}\text { Association } \\
\text { N of Valid } \\
\text { Cases }\end{array}$ & 13,354 & 1 &, 000 \\
\multicolumn{1}{c}{ Dari hasil } & 65 & & \\
\hline
\end{tabular}

tingkat pengetahuan tentang proses menua dengan tingkat depresi pada warga di Desa Majasto Tawangsari Sukoharjo diperoleh hasil uji dengan Chi-Square program SPSS versi 18.0 dengan $\alpha=5 \%(0.05)$ diperoleh $p<0.001$ sehingga nilai $p$ $<0.05$, yang berarti Ho ditolak dan Ha diterima, sehingga dapat ditarik kesimpulan bahwa ada hubungan tingkat pengetahuan tentang proses menua dengan tingkat depresi pada warga di Desa Majasto Tawangsari Sukoharjo.

\section{PEMBAHASAN}

1. Pengetahuan tentang proses menua

Dari hasil tabel 1 dapat dicermati bahwa presentase pada kategori tingkat pengetahuan tentang proses menua pada responden di Desa Majasto Tawangsari Sukoharjo adalah rendah sejumlah 5 responden (8\%), cukup atau sedang yaitu 48 responden (74\%) dan tinggi 12 responden (18\%). Dari hasil tersebut dapat diketahui bahwa sebagian besar responden memiliki pengetahuan yang cukup tentang proses menua. Dari wawancara dengan beberapa responden mereka mengungkapkan pernah 
mendapatkan informasi tentang proses menua dari penyuluhan kesehatan yang didapatkan saat mengikuti posyandu lansia dan dari media-media informasi lain seperti televisi dan majalah. Seperti yang diungkapkan oleh Paramita (2010) pengetahuan dapat diperoleh dari informasi baik secara lisan maupun tulisan, dari pengalaman seseorang dari fakta atau kenyataan dari mendengar radio, melihat dan sebagainya serta dapat diperoleh dari pengalaman dan berdasarkan pemikiran kritis. Paparan informasi yang diperoleh dari media-media tersebut dapat berpengaruh pada peningkatan pengetahuan responden tentang proses menua. Mubarak (2011) juga mengatakan jika kemudahan untuk memperoleh suatu informasi dapat mempercepat seseorang memperoleh pengetahuan-pengetahuan baru. Informasi yang diperoleh seseorang akan dapat merangsang pikiran dan kemampuan seseorang serta menambah pengetahuan. Sehingga semakin mudah dan banyak informasi yang diperoleh maka pengetahuanya akan suatu hal semakin banyak.

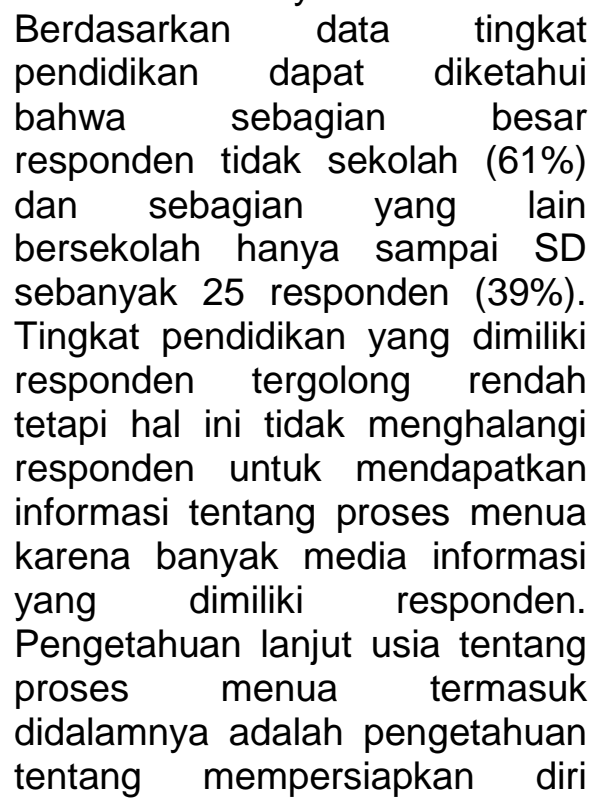

menghadapi masa tua. Pengetahuan tersebut selanjutnya akan diaplikasikan menjadi usaha-usaha untuk mempersiapkan keuangan, fisik dan psikologis.

2. Tingkat Depresi

Hasil penelitian tentang tingkat depresi di Desa Majasto Tawangsari Sukoharjo seperti yang tercantum dalam tabel 2 terdapat 6 responden (9\%) mengalami depresi berat, 23 responden (36\%) mengalami depresi sedang dan sebagian besar responden sejumlah 36 orang $(55 \%)$ tidak mengalami depresi. Data tentang tingkat depresi pada lanjut usia ini didapatkan dengan alat ukur Geriatric Depression Scale (GDS). Depresi yang dialami responden ditandai dengan kemurungan, kelesuan, ketiadaan gairah hidup, perasaan tidak berguna dan putus asa. Seperti yang diungkapkan oleh Yosep (2007) depresi adalah suatu gangguan tonus perasaan yang ditandai dengan kesedihan, apatis, pesismisme dan kesepian.

Depresi berat dan sedang yang dialami responden dapat disebabkan karena kurangnya persiapan dalam menghadapi masa tua. Seperti yang diungkapkan oleh Maryam, et al. (2008) pada saat memasuki usia lanjut individu akan mengalami berbagai macam perubahan kearah kemunduran seperti kemunduran fisik atau berbagai masalah kesehatan, mental dan sosial secara bertahap. Apabila individu tidak mempersiapkan diri untuk menghadapi masa usia lanjut ini dapat terjadi gangguan psikologis meliputi frustasi, kesepian, takut kehilangan kebebasan, takut menghadapi kematian, perubahan keinginan, depresi, dan kecemasan. Hal ini 
juga sesuai dengan yang diungkapkan oleh Aspiani (2014) bahwa pada lanjut usia permasalahan yang menarik adalah kekurangan kemampuan dalam beradaptasi secara psikologis terhadap perubahan yang terjadi pada dirinya. Penurunan kemampuan beradaptasi terhadap perubahan dan stres lingkungan sering menyebabkan depresi. Rasa kurang percaya diri atau tidak berdaya dan selalu menganggap telah gagal karena harus menghabiskan sisa hidupnya jauh dari orang-orang yang dicintai mengakibatkan lansia memandang masa depan suram dan selalu menyesali diri.

3. Hubungan antara Pengetahuan tentang Proses Menua dengan Tingkat Depresi di Desa Majasto Tawangsari Sukoharjo

Dari hasil penelitian hubungan tingkat pengetahuan tentang proses menua dengan tingkat depresi pada warga di Desa Majasto Tawangsari Sukoharjo diperoleh hasil uji dengan ChiSquare program SPSS versi 18.0 dengan $\alpha=5 \%(0.05)$ diperoleh $p$ $<0.001$ sehingga nilai $p<0.05$, yang berarti $\mathrm{Ho}$ ditolak dan $\mathrm{Ha}$ diterima, sehingga dapat ditarik kesimpulan bahwa ada hubungan tingkat pengetahuan tentang proses menua dengan tingkat depresi pada warga di Desa Majasto Tawangsari Sukoharjo.

Hasil analisa hubungan antara tingkat pengetahuan tentang proses menua dan tingkat depresi pada lansia di desa Majasto menyimpulkan bahwa semakin tinggi pengetahuan tentang proses menua semakin rendah kejadian depresi. Pengetahuan responden tentang proses menua baik pengertian, tanda-tanda penuaan, persiapan menghadapi masa tua menentukan langkah-langkah yang diambil lansia untuk mempersiapkan diri menghadapi masa tua sehingga dapat menurunkan kejadian depresi. Seperti yang dapat dilihat dari hasil tabulasi silang tingkat pengetahuan dan tingkat depresi di desa Majasto responden dengan tingkat pengetahuan tinggi tidak ada yang mengalami depresi berat, 2 responden mengalami depresi sedang dan 10 responden tidak mengalami depresi dan 3 responden dengan tingkat pengetahuan rendah mengalami depresi berat dan 2 responden mengalami depresi sedang. Hal ini seperti yang diungkapkan oleh Azizah (2011) bahwa depresi dapat dicegah dengan pendekatan kognitif yaitu pendekatan yang bertujuan untuk mengubah pandangan dan pola pikir tentang keberhasilan masa lalu dan sekarang dengan cara mengidentifikasi pemikiran negatif yang mempengaruhi suasana hati dan tingkah laku, menguji individu untuk menentukan apakah pemikirannya benar dan menggantikan pikiran yang tidak tepat dengan yang lebih baik. Tingkat pengetahuan yang cukup tentang proses menua menjadi bekal untuk mempersiapkan diri menghadapi masa tua sehingga terjadinya depresi karena perubahan-perubahan atau kemunduran-kemunduran yang terjadi di masa ini dapat dihindari. Hal tersebut sesuai dengan penelitian yang dilakukan oleh Yulnia (2011) dengan hasil penelitian ada hubungan tingkat pengetahuan penderita depresi tentang depresi dengan sikap mencegah kekambuhan depresi di wilayah kerja Puskesmas Nusukan Banjarsari Surakarta. Pada penelitian ini menyatakan bahwa semakin baik pengetahuan responden maka 
pemahaman responden semakin baik dan tindakan pencegahan akan semakin baik.

Selama melakukan penelitian, peneliti menemui beberapa hambatan diantaranya situasi lingkungan penelitian yang luas sehingga peneliti membutuhkan beberapa hari untuk pengambilan data dan responden yang berusia lanjut membutuhkan penjelasan yang lebih banyak untuk pengisian kuesioner. Namun penelitian dapat berjalan lancar sesuai dengan waktu penelitian yang ditargetkan.

\section{KESIMPULAN}

Dari hasil penelitian hubungan tingkat pengetahuan tentang proses menua dengan tingkat depresi pada lansia di Desa Majasto Tawangsari Sukoharjo diperoleh hasil uji dengan Chi-Square program SPSS versi 18.0 dengan $\alpha=5 \%(0.05)$ diperoleh $p<0.001$ sehingga nilai $p$ $<0.05$, yang berarti Ho ditolak dan Ha diterima, sehingga dapat ditarik kesimpulan bahwa ada hubungan tingkat pengetahuan tentang proses menua dengan tingkat depresi pada lansia di Desa Majasto Tawangsari Sukoharjo.

\section{SARAN}

1. Dari hasil penelitian didapatkan hasil ada hubungan antara tingkat pengetahuan tentang proses menua dengan tingkat depresi pada lansia di Desa Majasto Tawangsari Sukoharjo, diharapkan Dinas Kesehatan atau Puskesmas dapat memberikan penyuluhan tentang persiapan-persiapan menghadapi masa tua untuk mencegah depresi.

2. Diharapkan responden dapat meningkatkan pengetahuan tentang pencegahan depresi dengan menggunakan mediamedia informasi seperti mengikuti pendidikan kesehatan tentang proses menua atau melalui media yang lain seperti koran, majalah dan televisi.

3. Diharapkan peneliti selanjutnya dapat melakukan penelitian yang berkaitan dengan tingkat depresi pada lanjut usia dilihat dari faktorfaktor yang lain seperti riwayat pekerjaan, jenis kelamin dan tingkat pendidikan.

\section{DAFTAR PUSTAKA}

Azizah, L. M. 2011. Keperawatan Lanjut Usia. Graha IImu, Yogyakarta.

Asipiani, R. Y. 2014. Asuhan Keperawatan Gerontik. Trans Info Media, Jakarta.

Hidayat, A. A. 2008. Riset Keperawatan dan Teknik Penulisan IImiah. Salemba Medika, Jakarta. . 2009. Metode Penelitian Keperawatan dan Teknik Analisis Data. Salemba Medika Jakarta.

Kelliat, B. A., et al. 2011. Keperawatan Kesehatan Jiwa Komunitas. EGC, Jakarta.

Maryam, R. S. et al. 2008. Mengenal Lanjut Usia dan Perawatanya. Salemba Medika, Jakarta.

Mubarak, W. I. 2011. Promosi Kesehatan untuk Kebidanan. Salemba Medika, Jakarta.

Nugroho, W. 2008. Keperawatan Gerontik \& Gariatrik, Ed 3. EGC, Jakarta.

Paramita, D. P. 2010. Hubungan Tingkat Pengetahuan tentang Dismenorea dengan Perilaku Penanganan Dismenorea pada Siswi SMK YPKK I Sleman Yogyakarta. https://core.ac.uk/download/fil es/478/12345254.pdf. Diakses tanggal 25 Maret 2016

Potter, A. P. dan Perry, A. G. 2005. Buku Ajar Fundamental Keperawatan. Ed 4. Jakarta: EGC. 
•KOsคเด•• JIK. Vol. 4 No. 2 September 2016

Sudoyo, A. 2007. Buku Ajar IImu Penyakit Dalam. Departemen Ilmu Penyakit Dalam Fakultas Kedokteran Universitas Indonesia, Jakarta.

Yosep, I. 2007. Keperawatan Jiwa. Refika Aditama, Bandung.

Yulnia, F. P. 2012. Hubungan Tingkat Pengetahuan Penderita Depresi tentang Depresi dengan Sikap Mencegah Kekambuhan Depresi di Wilayah Kerja Puskesmas Nusukan Banjarsari Surakarta. Surakarta: Universitas Muhammadiyah Surakarta.

1Dosen AKPER Panti Kosala Surakarta

2Mahasiswa AKPER Panti Kosala Surakarta 